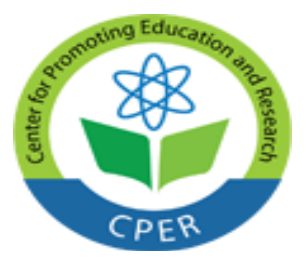

\title{
THE CONCEPTUAL PAPER ON TRUST AND ZAKAT COMPLIANCE AMONG INDIVIDUALS
}

\author{
Dr. Yaty Sulaiman \\ Universiti Utara Malaysia \\ Kedah, Malaysia
}

Abstract

This aim of the conceptual paper is to study the relationship between the trust of the society towards Zakat Institution and their compliance on zakat. In other words, it is consider as an early study of conceptual framework to examine the factors that influence the individual trust towards Zakat Institution. Theory of Reasoned Action was applied in the study to investigate the individual's attitude and their compliance towards paying zakat. There also some recommendations for Zakat Institution to increase their performance and boost up the percentage of Muslim zakat payers to fulfil their obligation.

\section{Keywords: Trust, Compliance, Theory of Reasoned Action, Zakat Institution}

\section{INTRODUCTION}

Surah Taubah verse 60 from the Quran mentioned that zakat is for people in need (Asnaf). Zakat is the third from five pillars of Islam as a charitable giving from some of our wealth. It is an order from Allah to whom are able to do so and necessary as a process to reform or restructure both our financial and spiritual as a Muslim (Z. Bidin et al., 2016). In addition, zakat can avoid us from sadness and anxiety besides it can contribute to the stabilization of the Islamic economy which is one of the principals to stability and prosperity. In other words, zakat is the purification of wealth because it allows the individual to achieve balance and encourages for new growth in their wealth.

Basically, there are five principles in paying the zakat which include the payer must declare to Allah his intention to give the zakat. Besides that, the amount of zakat must be paid on the day that it is due. After the offering, the person who pays zakat must not exaggerate his spending more than usual means. The Zakat must be pure and be willing to pay from the payer. If a person is not wealthy enough to pay the zakat, then they can compensate for it in other different ways such as presenting a good behavior towards others. The zakat collected by Zakat Institution must be distributed for those who are in need.

Zakat collection in Malaysia is institutionalized although it is a state matter. State Islamic Religion Councils (SIRCs) controlled the management and administration of zakat in Malaysia. The major objective of the establishment is to standardize all the Islamic Religious activities at the state level (M.S.A. Razimi et al, 2016). Kedah a state in Malaysia established Majlis Agama Islam Negeri Kedah (MAIK) which adopted Islamic law in the government system. MAIK made a continuous improvement through the legal process. This is due to enable the government of Islamic religious affairs effectively and follows with current development.

However, there are still low in compliance in the payment of zakat due to the increasing number of societies are saving their money, fixed deposit, and current saving accounts. Besides that, society has less trust towards the Zakat Institution in term of their integrity and distribution of zakat for the people in need. Muhammad, S. A., \& Saad, R. A. J. (2016) stated that, Zakat Institution will only sustain if there is a zakat payment from the society and effective distribution for people who deserved it. 


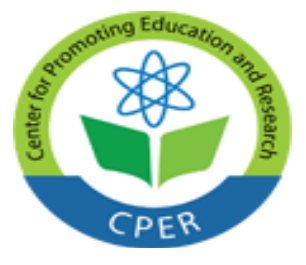

\section{CONCEPTUAL FRAMEWORK}

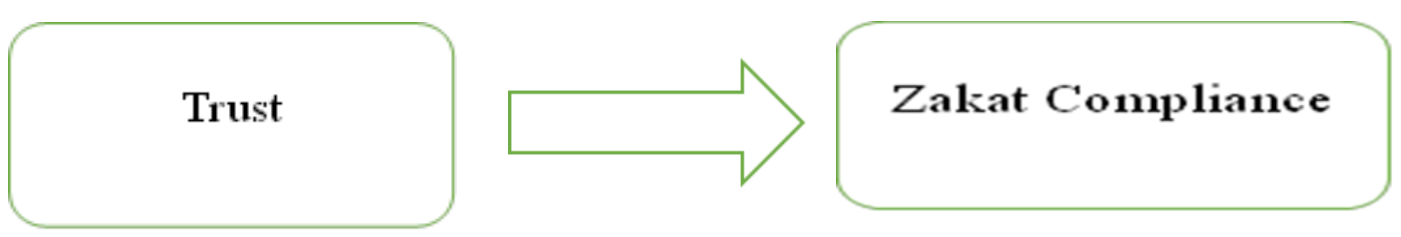

Figure 1: The Conceptual Framework

Figure 1 above shows the conceptual framework for this paper. The framework postulates that trust towards Zakat Institution is influencing as the factor towards the compliance in paying zakat. The Theory of Reasoned Action is applied in this conceptual paper. Besides, the literature review below found that trust towards Zakat Institution is the potential factor that influences the compliance of society in paying their zakat.

Lastly, the framework also proposes a positive relationship between the independent variable and the dependent variable. The relationship is supported by other scholars such as Z. Bidin et al., 2016; S.A. Muhammad and R.Al Jaffri Saas, 2016; and M.Z. Ghazali et al, 2016.

\section{LITERATURE REVIEW \\ Trust \\ Concept of Trust}

Trust is important in life and to gain trust from people is not easy. Rotter (1967) as cited in Zainal, H., Bakar, A. A., \& Saad, R. A. J. (2016) stated that trust is a word or promises in written or verbal form stands the individual or group is reliable. Another scholar Mayer et al (1995) as cited in Zainal, H., Bakar, A. A., \& Saad, R. A. J. (2016) defined trust as a desire of a party to look in advance to another party to do something urgent for him without any control of that party, which also supported by Curall and Inkpen (2002) said that trust is the willingness and without a pressure of an individual to accept the intentions or conduct of any other person which beyond his control.

In addition, McKnight and Chervany (2001); Nunkoo et al (2012) as cited in Noor, A. M., \& Saad, R. A. J. (2016) defined trust as a belief of a person that will act, as expected in a responsible way which will meet the expectation of another person who trusts them. Mikami and Inoguchi (2008) and Vigoda-Gadot (2006) as cited in Zainal, H., Bakar, A. A., \& Saad, R. A. J. (2016) stated that trust is based on the perception of a person itself. Trust is also can be included as a cultural norm to make space and gap and more opportunities to interact and communicate with people.

Therefore, from the multiple version of trust definition, it will be a failure factor in a group or individual if there is no trust amongst each other.

\section{Trust in Zakat}

Even though the total collection of zakat has been increased over the past decades, the zakat payment through its institution amongst Muslim business owners remains less encouraging. RM470 million was collected from the business segment in 2012 and it was the second largest contributor to the total zakat collection. Alias (2013) as cited in Ghazali, M. Z., Saad, R. A. J., \& Wahab, M. S. A. (2016) stated that there is $20 \%$ of its potential zakat revenue from this segment and the remaining $80 \%$ of uncollected zakat for about RM 1.85 billion remains as a huge potential for the authorities to have their share. This is because some of the Muslim payers opt to pay directly to the recipients.

Based on the National Council of Fatwa, it is compulsory for the Muslim to pay the zakat to the institution while any direct distribution of zakat to the eligible recipients is permissible. But however, it is sinful for disobeying 


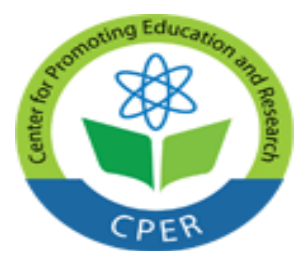

VOL: 5, ISSUE: 2

February/2019

E-ISSN: 2469-6501

(C) Center for Promoting Education and Research (CPER) USA

WwW.cpernet.org

the country's Islamic government decision. Wahid et al (2009) as cited in Ghazali, M. Z., Saad, R. A. J., \& Wahab, M. S. A. (2016) stated that the failure of paying zakat direct to distribution because as zakat payers have been dissatisfied with the inefficiency of zakat distribution by the institution. This can be supported by Sinar (2014) as cited in Ghazali, M. Z., Saad, R. A. J., \& Wahab, M. S. A. (2016) said that zakat payers have low trust towards the institution, especially in its capability to help the poor and destitute.

Therefore, the payers are preferring to pay their zakat to and transfer their contribution to the indirect channel (Muhammad et al, 2015; Wahid and Ahmad, 2014; Ismail et al, 2011 as cited in Ghazali, M. Z., Saad, R. A. J., \& Wahab, M. S. A., 2016). This is a concern towards the integrity of Zakat Institution in managing the public's fund.

As mentioned in The Quran, Surah at-Taubah verse 60 "Zakat is for the poor and the needy and those who are employed to administer and collect it, and for those whose hearts are to be won over, and for the freeing of human beings from bondage, and for those who hearts are overburdened with debts and for every struggle in God's cause, and for the wayfarer

\section{COMPLIANCE}

\section{Concept of Compliance}

There is no correlation between the religion and beliefs which can affect people action (Vitell, Paolillo \& Singh, 2005 as cited in Abashah et al, 2018). Angner \& Loewenstein (2007) as cited in Abashah et al (2018) supported this statement said that psychological for the behavior of people towards the circumstances have their logical explanation and there are 5 methods which can define people behavior. The first approach is assuming people as entirely rational and interested in the least effort. The second method is related to biological need compared to environmental stimuli which leads in psychodynamic tradition. The third method is through observation the action as interpersonal cognitive. The method follows with the causation on individual who attribute to an external factor which called classical behaviourism. Lastly, is exploring the concept of introspective.

There is a close relationship between zakat and religious obligation because whoever not paying zakat is consider as a person who disobeys the Islam obligation. This is supported by Aziz (2015) as cited in Abashah et al, 2018 said that the obediently towards Islam is closely related to some piety factors.

\section{Zakat Compliance}

Zakat compliance has been conducted in Malaysia. But however, there is still low in compliance behavior among the Muslim society in paying their zakat. Mohd Ali et al (2004) as cited in Z. Bidin et al., 2016 stated that in Wilayah Persekutuan there are approximately $4.2 \%$ of Muslims complete their obligation in paying zakat. In addition, Kamil (2002) and Kamil et al (1997) as cited in Z. Bidin et al., (2016) also have the same opinion in the northern region of Malaysia where only $35 \%$ pay zakat on employment income in Kedah and Perlis. The theory of reasoned action is used to predict the future of compliance intention on zakat on employment income.

Compliance has been long studied in the field of taxation but still hard and rare in the study of zakat. Kamil (2002) as cited in Noor, A. M., \& Saad, R. A. J. (2016) stated that, the adaption of tax compliance as the base of zakat compliance which referred to as the payment of zakat according to the rulings and regulations enacted by the zakat authorities. Compliance is a human behavior of a Muslim community to make decision either to comply or not to pay zakat on officially or unofficially channels according to the enactment and law implementation to get their satisfaction in life and hereafter (Sanep et al, 2011; Barizah and Rahim, 2007 as cited in Noor, A. M., \& Saad, R. A. J., 2016).

In addition, Ram (2010) as cited in Mohd Rahim, K., Ariffin, M. S., \& Abd Samad, N. (2011) stated that zakat compliance is a concept on the reason why the individual makes a decision to obey or disobey of command of 


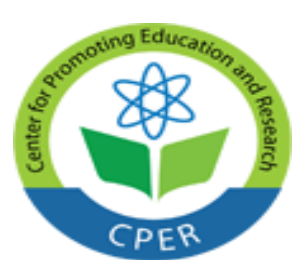

Allah, Islamic obligation and the rules issued by zakat authority. Therefore, from the concept, it is clear that compliance on zakat is more on fulfilling our obligation as a Muslims towards the satisfaction in the two life compared to compliance on tax where it is based on human regulation in order to avoid punishment in the world.

\section{THEORY OF REASONED ACTION}

This theory can be defined as an attitude of an individual that has a direct effect on the behavioural intention. Attitude is an individual that has a good or bad evaluation on a particular behavior (Ajren and Fishbein, 1980 as cited in Z. Bidin et al., 2016). The key point in this theory is intended as highlighted in the theory of reasoned action. Therefore, the theory of reason action can relate to zakat.

There is a positive relationship between attitudes and zakat on employment income and behavioural intention of giving zakat on employment income as revealed by Zainol and Kamil (2007) and Zainol, Kamil and Faridahwati as cited in Z. Bidin et al., 2016. Besides that, in Kedah, Malaysia, Farah Mastura and Zainol (2015) as cited in Z. Bidin et al., (2016) also stated that attitude to significantly influence to zakat compliance behavior on saving.

Other than that, Zainol et al (2009) and Zainol and Kamil (2007) as cited in Z. Bidin et al., (2016) said that in zakat environment have subjective norms with positively related to intention to pay zakat on employment income. This is supported by Farah Mastura and Zainol (2015) as cited in Z. Bidin et al., (2016) stated that in Kedah, subjective norms are significantly influenced zakat compliance behavior on saving.

\section{RECOMMENDATION}

The administration of Zakat Institution must be able to plan the strategies and revise the institute weaknesses to increase the collection of zakat in future when they can understand the relationship between the society trust towards the Zakat Institution and their compliance in paying zakat. Besides that, the State Islamic Religion Council also can increase their knowledge about zakat and understand more about the potential behavior of zakat payers.

Other than that, Zakat Institution also can promote zakat wider where they can introduce a scheme which zakat payers can personally distribute zakat to people in need (asnaf) using the money they had to pay to the institution. Through this, it can encourage society to pay their zakat and can increase the numbers of people paying zakat. In addition, Zakat Institution should resolve the problems and issues which arise from the internal of the organization.

Besides that, Torres-Moraga et al (2010) as cited on Ghazali, M. Z., Saad, R. A. J., \& Wahab, M. S. A. (2016) said that, Zakat Institution must come up clean and pure as a trust towards and institution is influenced by the contributor's confidence to continuously committed to supporting the entity.

\section{CONCLUSION}

As a conclusion, the trust of the society towards Zakat Institution is the factors of their obedience in paying their zakat as a Muslim to fulfill their satisfaction in life and hereafter. But however, there are still low in trust although the number of statistic shows the increasing of society in paying zakat in recent years. This is due to the management of Zakat Institution is poor which they failed to distribute the zakat collected to the people who are in need (asnaf). This can be clearly seen the number of poverty is still high in Malaysia. Therefore, to increase the percentage of society to pay zakat, Zakat Institution should monitor and analyze again their plan or strategy for their distribution process to help people in need. This can gain the trust from the society and help to complete their objectives as Zakat Institution.

\section{ACKNOWLEDGMENT}

Yaty Sulaiman is Senior Lecturer of Marketing, School of Business Management, College of Business, Universiti Utara Malaysia 06010 Sintok, Kedah, Malaysia. The author would like to thank Lembaga Zakat Negeri 


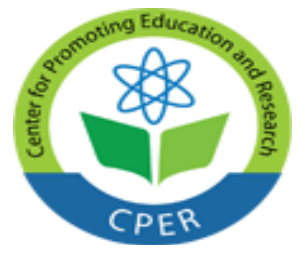

VOL: 5, ISSUE: 2

February/2019

https://ijbassnet.com/

E-ISSN: 2469-6501

(C) Center for Promoting Education and Research (CPER) USA

WWW.cpernet.org

Kedah (LZNK) and Institut Penyelidikan dan Inovasi Zakat (IPIZ)-UUM for granting this research under the Industry Research Grant Scheme and Research Innovation Management Centre (RIMC) Universiti Utara Malaysia.

\section{REFERENCES}

Ghazali, M. Z., Saad, R. A. J., \& Wahab, M. S. A. (2016). A Conceptual Framework for Examining Trust towards Zakat Institution. International Journal of Economics and Financial Issues, 6(7S), 98-102.

Ghazali, M. Z., Saad, R. A. J., \& Wahab, M. S. A. (2016). Proposing Factors Influencing Trust towards Zakat Institutions amongst Moslem Business Owners.

Muhammad, I. (2016). Factors that influence business zakat compliance among small and medium entrepreneurs.

Muhammad, S. A., \& Saad, R. A. J. (2016). Determinants of trust on zakat institutions and its dimensions on intention to pay zakat: a pilot study. Journal of Advanced Research in Business and Management Studies, 3(1), 40-46.

Oladimeji Abioye Mustafa, M., Har Sani Mohamad, M., \& Akhyar Adnan, M. (2013). Antecedents of Zakat Payers' Trust in an emerging zakat sector: an exploratory Study. Journal of Islamic Accounting and Business Research, 4(1), 4-25.

Razimi, A., Shahril, M., Romle, A. R., Erdris, M., \& Farid, M. (2016). Zakat Management in Malaysia: A Review. American-Eurasian Journal of Scientific Researc, 11(6), 453-457.

Saad, R. A. J., Wahab, M. S. A., \& Samsudin, M. A. M. (2016). Factors Influencing Business Zakah Compliance Behavior among Moslem Businessmen in Malaysia: A Research Model. Procedia-Social and Behavioral Sciences, 219, 654-659.

Zainal, H., Bakar, A.A., \& Saad, R. A. J. (2016). Reputation, Satisfaction of Zakat Distribution, and Service Quality as Determinant of Stakeholder Trust in Zakat Institutions. International Journal of Economics and Financial Issues, 6(7S), 72-76.

Noor, A. M., \& Saad, R. A. J. (2016). The Mediating Effect of Trust on the Relationship between Attitude and Perceived Service Quality towards Compliance Behavior of Zakah. International Journal of Economics and Financial Issues, 6(7S), 27-31.

Mohd Rahim, K., Ariffin, M. S., \& Abd Samad, N. (2011). Compliance behavior of business Zakat payment in malaysia: A theoretical economic exposition. In 8th International Conference on Islamic Economis and Finance (pp. 1-17). (2019, February 4). Retrieved from Kedah State Islamic Religious Council: http://www.maik.gov.my/en

Bidin, Z., Idris, K. M., \& Shamsudin, F. M. (2009). Predicting compliance intention on zakah on employment income in Malaysia: An application of reasoned action theory. Jurnal Pengurusan (UKM Journal of Management), 28. 